\title{
O Estado em face da Organização Racional de Trabalho
}

\author{
Alberto Saltiel
} séculos.

No comêço da História humana, era o trabalho considerado como castigo que os deuses impunham ao homem, em punição aos seus pecados. "Ganharás o teu pão com o suor do teu rosto" é a terrivel sentença com que Jeová condenou Adão e Eva pela sua desobediência.

Em tôdas as religiões, o "paraíso" simboliza o eterno gôzo dos prazeres e a completa ausência de qualquer atividade penosa ou trabalho. $\mathrm{O}$ contrário se dá com os infernos, que resumem a idéia de esforços continuos e sofrimentos eternos.

O trabalho como onus do vencido na guerra, já apresenta um progresso do sentimento de humanidade. É o trabalho escravo, que surge como uma evolução do costume de exterminar o inimigo vencido. Este passa a ser utilizado como animal de trabalho. escravo.

Em tôdas as civilizações, o progresșo social se baseou no trabalho

Embora no Ocidente a escravidão fôsse mais amena que no Oriente, essa forma de trabalho é considerada como a solução única para os problemas sociais, segundo afirmavam as maiores inteligências da Grécia e de Roma.

Aristóteles, na sua "Política" e Platão na República", aprovam e justificam a existência da escravidão, que na verdade, não poderia deixar de existir, se considerarmos o ciclo histórico em que viviam.

De Roma nos veio o têrmo trabalho, cujo significado era "corrêa de três pontas", usada para punir os escravos (tribilium).

Aos poucos, foi-se verificando um progresso nesse sistema de escravidão, que se transforma, lentamente, em trabalhos servil e finalmente livre.

Na Idade Média o trabalho foi representado pela servidão, até a grande crise social e econômica, motivada pelas "Cruzadas."

Elas enfraqueceram o poder dos nobres, acarretando a decadência do feudalismo. Os suzeranos ou senhores feudais viam-se obrigados pelas novas circunstâncias a conceder aos seus vassalos, inclusive aos servos da gleba, cartas de liberação, que lhes davam independência para executar trabalho
livre. 
Êsses novos liberados reuniam-se em instituições que denominavam corporações, guildas, confrarias, etc. O mercado de produtos das mais diversas cidades enriquece-se. Organizam-se as famosas feiras medievais e o intercâmbio econômico, há tanto reprimido, consegue frutificar.

Os estatutos dessas corporações e confrarias lançam, por sua vez, as bases do trabalho profissional e da sua decorrente especialização.

Já nos tempos modernos, porém, é que o trabalho consegue adquirir tôdas as suas prerrogativas de função social.

A Revolução Francesa, a Revolução Industrial, o surto do Capitalismo, a primeira Grande Guerra, são as grandes alavancas suficientemente poderosas para deslocar os obstáculos, criados pelos preconceitos contra o trabalho.

Êste pode, finalmente, adquirir um aspecto racional e organizado. As novas legislações vêm abolir o trabalho escravo e o trabalho servil obrigatório, para torná-los uma função respeitável, digna de qualquer ser humano, seja qual fôr a sua condição social.

Não há dúvida de que, com o desaparecimento do trabalho servil, surgiu, logo depois da Revolução Industrial, o trabalho proletário, que, embora constituindo um progresso, estava longe de constituir uma atividade digna de sêres humanos.

Mais tarde, porém, a constitucionalização dos direitos fundamentais do homem; a sistematização científica dos métodos de trabalho e da seleção e adaptação do homem ao trabalho; a organização sindicalista; o emprêgo mais difundido das máquinas; a regimentação das condições de trabalho, codificadas em tôdas as legislações das nações civilizadas - todos êsses fatôres concederam ao trabalho um grau elevado de organização e racionalismo.

Foi, enfim, reconhecido com função social imprescindivel ao progresso humano e à própria felicidade do individuo que a executa.

\section{A EVOLUÇÃO DA ORGANIZAÇÃO RACIONAL}

A História da Organização Racional começou, sem dúvida com a sistematização das idéias, depois da sua liberação dos princípios religiosos que, nas filosofias orientais, principalmente na Îndia, China e no Oriente Próximo, ainda estavam intimamente ligados aos conhecimentos gerais de tôdas as ciências.

Nos livros sagrados das religiões orientais estavam resumidos também os conhecimentos históricos, artísticos e filosóficos de cada povo. A "Bíblia" dos hebreus, o "Corão" dos maometanos, e o "Zend-Avesta" de ZoroAstro, o "Tao-te-King" de Lao-Tsé, os quatro "Vedas" dos indus, são os melhores exemplos.

Foi na Grécia, como tanto se tem repetido, que a ciência realmente se originou livre do dogma e do preconceito, e em que a filosofia conseguiu separar-se da religião.

Sócrates define a idéia em si. Aristóteles fornece o método de orientação científica do pensamento, no "Organon" ou "Lógica." 
Não restam dúvidas de que, com a lógica aristotélica, começa a história da Organização Racional, que vai culminar no século XVII com o Criticismo de Kant. No século XIX, atinge as suas conseqüências práticas, com a organização politico-social.

A segunda etapa da Organização Racional é a da sistematização das ciências, distinguindo-se, entre os precursores, Rogério e FranCIS BACON, que adotaram o método experimental do trabalho. O "Novum Organum" de FrANCIS BACON assinala um marco no desenvolvimento da inteligência humana.

A ocidentalização dos conhecimentos matemáticos, físicos e químicos dos árabes e a sua grande difusão, muito contribuiram para que se encarassem as ciências através de um prisma bastante positivo.

Chegamos então à Idade Moderna.

No campo das ciências astronômicas e matemática surge René Descartes. Seu "Discurso sôbre o método" deu à organização das ciências um enorme impulso, pelos fundamentos de análise e da sintese, por êle preconizadas como métodos de raciocínio.

Emanuel Kant, um dos maiores expoentes da Inteligência humana, foi o verdadeiro criador do racionalismo científico, baseado no criticismo. Seus maiores livros são a "Crítica da Razão Pura" e a "Crítica da Razão Prática."

Com o criticismo, KANT racionaliza a filosofia e abre novas perspectiva para a ciência.

Finalmente, em plena fase da organização racional das ciências, surgem Adam Smith, Herbert Spencer e Augusto Comte, que em verdade, foram os sistematizadores das ciências econômicas e sociais.

Adam Smith, com o seu livro "Das riquezas das Nações", assentou as bases científicas, da Economia Política, cuja origem porém, é atribuida a Xinofonte, autor de um trabalho sôbre economia doméstica, donde se originou a denominação dessa ciência.

Embora os mercantilistas já tivessem feito estudos sôbre a Economia social e politica, suas observações estavam demasiadamente eivadas de preconceitos nacionalistas, e só depois que A. Smith criou a Escola Econômica Liberal foi que a Economia Política tomou os seus fundamentos científicos.

Como ciência que é dos fenômenos que regem a produção, a distribuição e o consumo das riquezas, natural que a mesma tivesse importância decisiva sôbre a ciência da Organização do Trabalho.

O Evolucionismo de Herbert Spencer abriu novas possibilidades ao mundo científico. Augusto Comte, com o seu positivismo, representa outro passo para a frente. As ciências sociais adquirem seus foros de autonomia e Sistematização.

A Sociologia, principalmente, veio dar à ciência do trabalho organizado o fundamento das relações humanas no grupo, para melhor estudo e compreensão do trabalho coletivo. 
Cabe, sem dúvida alguma, o maior destaque, no setor do trabalho, aos estudos realizados pelos sociólogos EMIL DurKCHEIM (no seu livro "Divisão do Trabalho) e GABRIEL TARDE, que se notabilizou pelos seus estudos psicosociológicos.

Justamente nessa fase, o trabalho foi estudado através dos novos ramos das ciências sociais recém-criadas, como a Riologia, a Fisiologia, a Psicologia, a Estatística etc.

$\mathrm{Na}$ terceira fase da História da Organização Racional, em que se deu a sistematização dos fenômenos politicos sociais, é que vemos desenrolarem-se os grandes acontecimentos históricos que vão dar ao trabalho uma nova feição e uma maior importância na história humana.

Com o desenvolvimento dos ciclos da Economia Doméstica para a da Cidade, desta para a Economia Nacional e finalmente para a Economia Internacional, é que, como afirmam Karl Bluscher e ERnesto WagnermanN (citados por Mendonça Junior), o trabalho atinge o seu pleno apogeu, considerado como fato social.

Grandes acontecimentos históricos se produzem, alargando o âmbito das idéias, destruindo preconceitos que haviam, durante séculos, separado os homens, pela interposição de barreiras raciais, nacionais, religiosas, culturais e de castas.

A Reforma religiosa, após as guerras que provocou, trouxe uma nova aspiração de tolerância para com as crenças alheias. O Parlamentarismo inglês dá uma representação popular ao Govêrno. O movimento do Enciclopedismo atravessa as fronteiras da França, lançando sôbre os espíritos, na Europa e na jovem América, as sementes de um ideal de igualdade humana, que só fora antes encarado através do prisma religioso, nas palavras de Cristo. Rousseau, Voltaire, Diderot, D'Alembert, difundem as idéias liberais que vão originar a Revolução Francesa de 1789 , com tôdas as suas conseqüências para as classes menos favorecidas, as únicas a quem cabia o onus do trabalho.

A Constituição francesa de 1791 preconiza, de forma categórica, a liberdade profissional, tendo sido, aliás, precedida pela Declaração dos Direitos do Homem.

Com o surto da máquina a vapor e a difusão do seu emprêgo em quase tôdas as indústrias, opera-se a grande Revolução Industrial. Modificam-se os processos da produção, e o homem é libertado do trabalho fôrça. para se ocupar do trabalho de raciocínio, que é o govêrno da máquina.

A Constituição de Weimar, o Tratado de Versalhes e a Carta do Atlântico, trazem a sua contribuição para a regulamentação do trabalho, atribuindo nova dignidade ao trabalhador.

Estamos já na fase em que as leis do trabalho são confiadas a organismos internacionais: o Departamento do Trabalho da Liga das Nações e o da Organização das Nações Unidas. E nêles muito se tem feito para a racionalização e o desenvolvimento científico do trabalho em todo o mundo. 
Como vimos, a Organização Político-Social afetou profundamente o conceito do trabalho, atribuindo-lhe nova importância e nova dignidade. Deixou de ser uma atividade humilhante relegada a uma simples classe social, como nos tempos do trabalho escravo, servil e proletário.

Tornou-se uma função social, realizada por tôdas as classes. É uma atividade que honra o seu agente, e, de acôrdo com as cartas constitucionais de algumas nações, o seu exercício importa na obtenção dos próprios direitos politicos.

Pelo art. 145, parágrafo único, em fase da nossa Carta Magna, trabalho é uma obrigação social. 